\title{
Can the Modified-Conventional Teaching Method be Effective for Motivating Students' Foreign Language Context?
}

\author{
$1^{\text {st }}$ Gede Ginaya \\ Tourism Department \\ State Polytechnic of Bali \\ Badung, Indonesia \\ ginaya@pnb.ac.id
$4^{\text {th }}$ Luh Nyoman Chandra Handayani
Accounting Department
State Polytechnic of Bali
Badung, Indonesia
nyomanchandrahandayani@pnb.ac.id

\author{
$2^{\text {nd }}$ I Wayan Jendra \\ Tourism Department \\ State Polytechnic of Bali \\ Badung, Indonesia
}

$5^{\text {th }}$ I Made Ardana Putra

Department of Business Administration

State Polytechnic of Bali

Badung, Indonesia

ardana_rena@pnb.ac.id

\author{
$3^{\text {rd }}$ I Nyoman Kanca \\ Tourism Department \\ State Polytechnic of Bali \\ Badung, Indonesia
}

\begin{abstract}
Students were often confused and forced into silence when they communicate in English. This condition became a problem during the teaching-learning process and may eventually lead to poor speaking ability. Modified-Conventional method, which imbedded to the student center learning (SCL) in a collaborative learning can be a solution to address the aforementioned condition. The reason for the hypothesis above is the presence of the underlying principles of such the innovative teaching that can foster students' motivation, both intrinsically and extrinsically, towards the foreign language learning. The objective of this study is finding out the effectiveness of implementing the modified-conventional method in a collaborative learning, to the students' learning motivation of EFL context which could boost their oral communication. Participants were 30 fourth semester students (16 males and 14 females) enrolled in a three-year diploma program in Travel and Tourism Business, State Polytechnic of Bali. The students were given communicative activities and practices which were carefully designed so as to necessitate the implementation of the modified-conventional method. Data were collected through classroom action-based research procedures starting from planning, action, observation, and reflection. The mean was used measure of the students' speaking achievement in order to identify any statistically significant improvements following the intervention. Meanwhile, qualitative data was analyzed based on the whole observation of the action and the result of the questionnaires. The result of the pre-test indicated that the students' oral communication categorized into low. Its mean score was only 55.29. Meanwhile, the results of test in the three cycles were respectively $68.30,75.12$, and 86.22 . It can be concluded that the students' learning motivation increased highly due to the conducive learning atmosphere created as they could get engage, encourage, enthusiastic, and explored in each learning cycle. Consequently, it could improve their oral communication significantly. Limitations and suggestions for successful applied
\end{abstract}

action-integrated instruction and implications for future research are provided.

Keywords-modified-conventional method, innovative teaching, learning motivation, foreign language, oral communication

\section{INTRODUCTION}

In line with the needs and demands of society that is exposed with the development of science and technology, the educational system should be regularly reviewed in order it attains development and innovation against these demands. The policy of developing curriculum in higher education, for instance, is not separated from the huge attention towards the quality assurance of an education for welcoming the global era which is integrated to the information and communication technology (ICT). The advance of ICT has risen the such terms as a digital era, $21^{\text {st }}$ century or disruption 4.O. According to Ali and Abdallaabdalganaem [1] integration of technology in education has increasingly become an important concern in education not only in developed countries, but in developing countries as well. Integrating technology to classroom instruction is in line with the research done by Ginaya et al [2] entitles the effects of blended learning to students' speaking ability as study of utilizing technology to strengthen conventional face-to-face instruction. Delors (1966) in Marhaeni [3] reported their results of investigation to the United Nations through the article entitles "Learning the Treasure Within". This report then published into a book which becomes a reference for developing education in a country. Learning the Treasure within emphasizes that learning is a treasure in oneself, which means that something that exists in every human fellow being along his/her life [3]. Marhaeni 
further states that the learning concept also requires something to be embedded to everyone that for the human progress, then long life education should be an ownership, which is alive and unite in the attitude, aptitude, knowledge, and skills. Therefore, it has been set up four pillars of education which becomes the foundation for the development of education in all levels. The four pillars of the education are learning to know, learning to do, learning to be, and learning to live together.

Gates, Myhrvorld, and Rinearson, 1966 [3] stated that the $21^{\text {st }}$ century era nowadays is known as the age of knowledge as the main foundation for various aspects of life. The learning paradigm of the $21^{\text {st }}$ century emphasizes that education is in the knowledge age by accelerating the enriching knowledge enhancement. According to Frietas and Yapp, 2005 [3]) this paradigm emphasizes on students' ability to communicate and collaborate as it is stated further by Marhaeni that such kind of ability can be achieved through the implementation of the appropriate teaching learning method from the side of mastery materials and skills. In this $21^{\text {st }}$ century, the education is getting more and more important in order to assure the learner participants possess learning skill and to innovate, the competency in using technology and information media and are able to work and survive by utilizing the competencies (life skills) [3]).

Therefore, the 21 century's competencies are including (1) life and career skills, (2) learning and innovation skills, and (3) information media and technology skills [3]. Trilling and Fadel, 2009 in Marhaeni [3] stated that the three skills are summarized into a scheme which is called the $21^{\text {st }}$ century knowledge-skills rainbow. In line with this view, The American Association of Colleges for Teacher Education (AACTE) advisory group and the strategic council of the Partnership for 21st Century Skills in Greenhill [4] have approved the following core principles, representing a shared vision for integrating 21 st century skills into educator preparation.

Based on the source from American Association of Colleges of Teacher Education 2008, US Department of Education 2010 [4] in order to meet the challenges and demands of the profession, AACTE is leading reform efforts some of them can be stated the two upmost crucial that "Engage prospective teachers in creating instruction aligned with their state's curriculum standards, effectively interpreting assessment results, responding to students' learning needs, and cultivating a passion for learning that will support students for a lifetime, and meet the demands of the global economy by exemplifying, and embedding in instruction, the mastery of 21 st century skills such as critical thinking, problemsolving, communication, collaboration and creativity and innovation. This includes the application of technology to support more robust instructional methods and understanding the relationship between content, pedagogy and technology through dissemination of Technological Pedagogical Content Knowledge (TPCK) theory and research".
P21's or Framework for 21st Century Learning in "Framework for $21^{\text {st }}$ Century" n.d., para 3 [5] was developed with input from teachers, education experts, and business leaders to define and illustrate the skills and knowledge students need to succeed in work, life and citizenship, as well as the support systems necessary for 21st century learning outcomes. It has been used by thousands of educators and hundreds of schools in the U.S. and abroad to put 21 st century skills at the center of learning. The P21 Framework represents both 21 st century student outcomes (as represented by the arches of the rainbow) and support systems (as represented by the pools at the bottom).

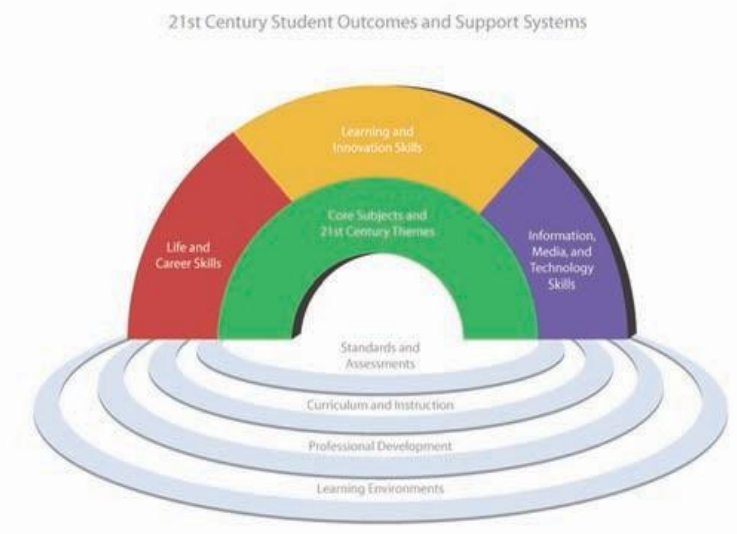

Fig. 1. P21 Framework for $21^{\text {st }}$ Century Learning Source: www.p21.org

In line with the paradigm of the $21^{\text {st }}$ century education above, in Indonesia it has been set up the Indonesia National qualification framework (KKNI) through Perpres RI No. 8 year 2012. KKNI is the competency-qualification level which can be pairing, equalizing, integrating among field of education and field of job training as well as work experience on behalf of giving recognition of work competence according to the structure of work in various sectors. KKNI demanding a certain work of certain competencies for career path or specific work. From the above provisions, then the establishment of work world competence is the core of any process that is experienced by the learning participants in all levels of education that followed. In other words, the formation of competence must be through education. Marhaeni [3] explained that in reference with the competency concept, then the four pillars of education are the core of the competencies where for the sake of fulfilling the demands of job vacancies, learning to do in the form of able to do in every personnel is the top of the peak as it is a result of the formation of the four pillars. Consequently, the competencies that is established through the process of education will be showed from the capability of the personnel to solve problems faced holistically.

In relation with students learning motivation, Shahidzade [6] asked a question of which strategies can motivate EFL learners more in foreign language context? And how? It is interesting to give answer to this question and share a discussion concerning it. Some expertise either teachers or linguists attempt at answering the question in various insights. 
Ahmed in Shahidzade [6] states that Collaborative learning can be effective for motivating students in foreign language context. Any other activities that involve learners in learning process rather than being passive listeners can motivate them too. Hadi in Shahidzade [6] puts forward the student center learning (SCL) strategies, with open discussion, was effective to use. The essence of SCL then elaborates further by Mustafa in Shahidzade [6] by saying that student-centered learning which can be established through the practice of the Communicative Language Teaching Approach Regarding the effective teaching method being implemented in classroom instruction, Hmidani in Shahidzade [6] thinks that there is not one single strategy that can best motivate learners in foreign language context. The teacher should be sensible to the reactions of the students on a certain strategy and enhance it with diverse activities. The teacher should also be sensible to the learning styles of his/her students and adapt his/ her strategy accordingly.

Biria in Shahidzade [6] added an answer concerning this discussion by stating that "in the postmodern era, the strategies for teaching foreign languages mostly focus on learners' critical needs and their role in the process of learning. The ENGAGE model of learning is a pedagogically effective model of collaborative, problem-solving and learner-centered program based on critical thinking whereby the teacher tries to mentally energize learners for realizing how important learning is to their future goals. In fact, professor Hultsey's ENGAGE Model reflects the related strategies that actually produce better results in the teaching / learning EFL contexts" [6].

From the theoretical point of view of teaching English as a foreign language, teachers have endeavoured to apply a number of approaches in the classroom. Among the approaches, it can be said that there are two of them well recognized on the part of the teachers. They may firstly present the students with new key language items based on the situational or functional context and then they give the students an opportunity to practice them (a deductive approach) or the students may practice a set of patterns and then be led to derive at their own generalization (an inductive approach). Even though both approaches represent different philosophical positions about the nature of learning, teachers should adapt techniques from each of them since it is also considering the characteristics of students in one class are so heterogeneous.

The tendency of learning as an active process, therefore, is preferable to the alternative for all, or most teaching learning activities nowadays. This evidence may arise due to the intention to reduce teachers' domination during the classroom activities as its consequence teachers are getting away from a teacher-centered which is regarded as a conventional method. Somawati et al [7] states that the conventional English learning method was found less effective to support communicative language teaching (CLT) to achieve students' communicative competence. In reflection from the stated fact, it can be applied the opposite style of learning which is called a student-centered learning (SCL). Committing SCL in classroom means actively involving students both intellectually and emotionally. Its essence of learning as an active process, is principally underlined by both cognitive and behavioral views of learning. The perception of new relationships among concepts, the arrangement of one already knows and understands as well as the process of providing rewards and stimuli are actively done [8].

Learning English with modified-conventional method could be an appropriate solution to be implemented. This learning method is developed from discovery learning as the opposite of expository learning. Actually, discovery learning itself is firstly introduced by Jerome Bruner in 1960 [9]. According to Richards and Schmidt [10] discovery learning is where "learners develop processes associated with discovery and inquiry by observing, inferring, formulating hypotheses, predicting and communicating. Holesinska [11] states that discovery learning strategy is the most practical and encouraging example of active learning strategy in which the students have to work out rules and find the text concept by themselves. Similarly, Thorsett [9] defined discovery learning as a learning situation in which the principal content of what is to be learned is not given, but must be independently discovered by the learner, making the student becomes an active participant in his learning. Balin [12] gave a solid definition of discovery learning as a strategy that encourages students to arrive at conclusion based upon their own activities and observation. This is also supported by Nutting [13] that this strategy can also bring out students' creativity, since there are two explorative activities taken by them namely observation and experimenting.

According to Saumell [14] modified-conventional method is a modified inductive approach in which there is exposure to language first, followed by the use of inference, and finally an explicit focus on rules and practice. She further states that here are cognitive, linguistic, and social benefits. Each benefit of this approach can be elaborated as (1) cognitive benefits are attained through encouraging analytic learning, exploits learners' cognitive skills, improves critical thinking skills, involves students in problem-solving tasks, helps learners become aware of and articulate their mental processes. Learners participate actively in the learning process, understand and remember better what they have worked out for themselves, (2) linguistic benefits are to resemble natural language learning/ language acquisition, if done in groups, it provides extra language practice, (3) social benefits are to increase student participation and foster collaboration, empowers learners thus enhancing autonomy and self-reliance. It is motivating for learners who enjoy the hands-on approach.

The role of the teacher, according to Saumell [14], is a facilitator, who guides learners in the right direction so as to avoid misunderstandings of the rules. It makes learning memorable since learners are actively involved in the process. It is meaningful because it involves the learners own reasoning. It can be concluded that modified-conventional method is aligned with more modern language learning theories that advocate student participation and the development of critical thinking skills and autonomy [15-18]. It relates to analytic learning and problem solving [19]. It helps 
learners engage in the learning process and thus make personal connections that anchor their learning [20]. It is a learnercentered approach that increases participation and fosters collaboration [21-22]. It empowers learners towards assuming responsibility for their own learning and becoming more autonomous [23]. It is therefore a valid and useful way of approaching language instruction at all levels of language ability.

\section{RESEARCH METHOD}

This study is conducted by using a classroom action-based research. Classroom action research can be defined as cyclic process of planning, action, observation, and reflection [24]. Thus, on the basis of this kind of research, the research involved three cycles in which each cycle was completed in two sessions. The implementation of this research includes the following.

\section{A. Subject of the Study}

The subject of the study was the fourth semester students in Travel and Tourism Study Program of Tourism Department, Bali State Polytechnic in the academic year 2018/2019. There were 30 students assigned to be the participants, 16 males and 14 females. This group of students was used as the subject of this present study based on the problem encountered by English team teaching that taught in the class. The teachers said that the students' class interaction and achievement on the oral task/practice were low. And also based on the problem encountered by the students in which they felt uninteresting in learning English as they were overwhelmed by such kinds of language expressions and grammar rules. They were often unfocused and getting prone in learning English.

\section{B. Research Instrument}

Instruments were used as a means of collecting the data. There were three kinds of instruments, which were used in the present study, namely teaching diary, observation sheets, and questionnaires. The teaching diary was used to observe the result of applying action both of the daily performance of the students' class interaction and their speaking ability. The observation sheets were used to record the students' oral communication that consists of 5 aspects: fluency, pronunciation, comprehension, vocabulary, and grammar. Beside that these sheets were also used to record the classroom interactions of the students, which included group, pair work interactions and interaction between the students and the teacher. The questionnaires were used to collect the data especially those that were related to the students' feeling, motivation, interest after doing the learning procedure using modified-conventional method given during the action.

\section{Research Procedure}

Since this present study used action-based research then its procedure was consisted of planning, action, observation, and reflection. Before the research was done, a preliminary speaking test was given to the students. The materials that were used in the test taken from the previous lesson book in which the teaching method used in learning English was mostly deductive as it is based on the chronical order of the book starting from presentation, practice, and communicative activities [2].

\section{Data Analysis}

The data were analyzed in two ways, namely quantitatively and qualitatively. The quantitative data were analyzed base on the speaking performance done by the students during the action. Here it measured about the achievement of the students who had been given action/treatment. In relation to this point, the mean score $(\mathrm{X})$ of the students as the subject of this study was used.

The total score of the students

$$
\text { Mean = ------------- }
$$

In addition, the mean score here was also used in order to know the improvement of the students' speaking ability after the application of the guided discovery-learning strategy in the class.

Meanwhile, the qualitative data were analyzed based on the result of the observation conducted after the action applied, and the result of the questionnaires. Here, the condition and the situation of the class during the teaching learning process took place, the interaction, the motivation, the attitude, and the interest of the students in doing the communicative activities and practices given by the researcher were analyzed in order to know the effectiveness of the learning strategy applied. And also, in order to know the problems that might be faced by the students during the teaching learning process, which caused they could not improve their speaking ability.

\section{RESULT AND DISCUSSION}

After doing the action in the 3 learning cycles, this part discusses about findings of each cycle done before. There were 15 topics discussed in the semester and each topic consisted of two teaching sessions as the learning method applied (modified-conventional method) was also consisted of two actions (communicative activities and practices) in every discussed topic. Before conducting the research, the researchers were carrying out the initial observation or preliminary test. The result of the preliminary-test showed poor result. The mean score of the students after being given an oral test by using a deductive method was only 55.288. This mean score was categorized into low beside that the students seemed not focused, uninterested, and often getting prone during the teaching learning process.

Based on the result of the preliminary observation, the research was started for the first cycle. In the planning step the researchers concerned on improving the students' speaking ability on the English subject matter using guided discovery- 
learning strategy. In this stage the instructional planning or teaching learning scenario and the instruments were prepared. After the planning step then it was conducted the action in which the treatment of brain storming, group discussion and pair work were given. The students perform the speaking activities and their performances were recorded in the observation form. At the end of the meeting session the speaking test was conducted to assess the students' speaking ability based on their performance in presenting dialogues and making a generalization of specific details from the discussed topics. The score of the speaking test is judged and calculated based on the scale suggested by Brown which consists of 5 components, namely grammar, vocabulary, comprehension, fluency, and pronunciation.

From the action given in the first cycle, then it was done an observation as the next step of this research. The test achieved by the students in this cycle was 68.30 showed that there was a good improvement if it was compared with the result of the pre-test that was only 55.288. Although the achievement of the students in this cycle higher than the pre-test, the whole observation of this cycle it was found that the students still feel not too confident and the slow students also found themselves still difficult to adjust with others in the group discussions. Knowing the weakness found in cycle 1 and then it was done a reflection as the last step of this cycle. As the reflection, it can be stated that the students needed facilitation during the process of exploration that could release the factors that cause the learning security in presenting the language activities and practices. The researchers thought that language games and role-plays could be the solution.

Similarly, with the previous cycle, the second cycle was started with the planning in which the researcher planned to apply language games and role plays in the communicative activities and practices in order the students felt comfortable in the discussion and then it was followed by preparing the teaching learning scenario. The action then was conducted in which the researchers asked the students to work in group of 5 or 6 persons and they did the communicative activities with language games and practices with role plays. In the observation step of this cycle it can be stated that the students began to feel comfortable. They became more active to participate in the group discussions and they were keen to perform acting in the role-play practices. As the result, their speaking ability was improved with the mean score of 72.86 . There was an improvement from the mean score of the students in the cycle 1 which was only 66.50. At the reflection step it can be described as there were some students who often borrow their friends' works in their respective group prior to well understand in order to be able to present orally at that time. This problem is known as short-term utility learning.

That was why for the next cycle every student was given WebQuest as tasks that were completed in small groups so that they had more interaction with each other and can jointly evaluate the information they find on a given website. The tasks included questions that involve some degree of higher level thinking, so having the students working in groups is a good way to generate a level of involvement and topic discussion that they would not encounter when working by themselves. Beside the tasks the students were also given problems to solve and each group of the students was encouraged to present different solutions.

In the planning step of the third cycle, the researchers designed the communicative activities and practices to be given to the students and then preparing the teaching learning scenario prior to give the action. The action was given in the form of communicative activities with WebQuest tasks and open-ended problems and then the students presented the topics they worked on the WebQuest orally and solution of the problem solving. In the observation step it was found that the students were really active in doing the communicative activities and practices. The students' mean score in this cycle was 81.25 which was the highest one. For the reflection of this cycle it can be stated that the students were really high motivated in learning English. However, this present study was only consisted of three cycles so the research was stopped.

The result of the students' achievement as it was stated in the pre-test and the three cycles could be shown in the following table.

$$
\text { TABLE 1. THE STUDENTS' ACHIEVEMENT }
$$

\begin{tabular}{|l|l|}
\hline \multicolumn{1}{|c|}{ Tests } & \multicolumn{1}{c|}{ Mean scores } \\
\hline Pre-test & 55.288 \\
\hline Cycle 1 & 68.30 \\
\hline Cycle 2 & 75.116 \\
\hline Cycle 3 & 86.22 \\
\hline
\end{tabular}

From the table above, it could be seen that the students' achievement in the tests given by the researchers increased from 55.29 at the pre-test, that was categorized into low, then it increased into 68.30 at the cycle $1,75.12$ at the cycle 2, and 86.22 at the cycle 3 . The result on the last cycle was categorized into very good. For the basis of the improvements stated above, the students' improvement in each cycle conducted could be shown in the following figure.

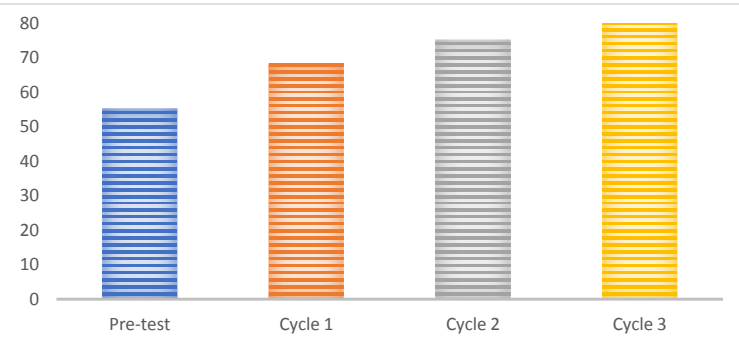

Fig. 2. The students' improvements in the test

From the result of the pre-test to the result of the test in cycle 1, it showed rather extreme improvement that was from 55.29 into 68.30. The advantages of the technique applied in cycle 1, which was facilitated with brain storming, group discussion, and pair works in the communicative activities and practices, could be stated as the students performed actively 
like questioning, responding others' and the teachers' questions. However, this technique was still not contributing an optimal result in which the students became not too confidence in asking and responding questions needed in the brain storming. This condition was happened because they still thought about mistakes of expressing the language items to be made in speaking, beside that some of them were still insecure working in group, especially the slow students who were still hesitant to learn from others.

As the cycle continued, the students' interactions were getting better in which they were challenged to be active in learning due to the technique applied in cycle 2 facilitated with language games and role plays in the communicative activities and practices. As a result, the students became more active participated in the learning since they found learning was fun and interesting. In addition, they could release their tension and stress in learning and they could also freely express their ideas in the activities beside that they could also share ideas with others in the group. Even, the slow students they could learn here from others and they got phrases, sentences, and grammatical points from their friends, which were used for oral presentation. And finally, in the cycle 3 facilitated by WebQuest and problem solving in the communicative activities and practices. In doing tasks with topics which were specially designed for the WebQuest, the students could get engaged in collaborative activities, shared learning experiences and new knowledge. They also tried to interact maximally in order to get better solution for the problems.

Those activities and practices were intended to stimulate their speaking creativity. So here, it could be clearly seen that the students' participation during the teaching learning process improved well. It also meant that the students enjoyed the class, which make them be able teste to use their English. Consequently, their speaking fluency is improved significantly from 56.45 in pre-test into 71.75 in cycle $1,80.36$ in cycle 2, and 87.68 in cycle 3. Meanwhile the number of mistakes in pronunciation and grammar could be reduced too. In addition, the three aspects of speaking ability (fluency, pronunciation, and grammar) were also supported by the other two aspects such as using more word choices and idioms (vocabulary) in expressing their ideas and also their ability to understand others in speaking English (comprehension). This research finding is in line with the study conducted by Ginaya et al [2]. The study revealed that the WebQuest project-based through utilizing technology to strengthen conventional instruction significantly improved the students' speaking ability. Such kind of project is considered truly supported the students' speaking ability as one of the language productive skills, since it is integrated several advantages of the language learning such as analysis, synthesis, evaluation, assessment, problem solving, and student creativity.

The description of achievement score which included the 5 components of speaking ability conducted in the 3 cycles could be shown in figure 3 below.

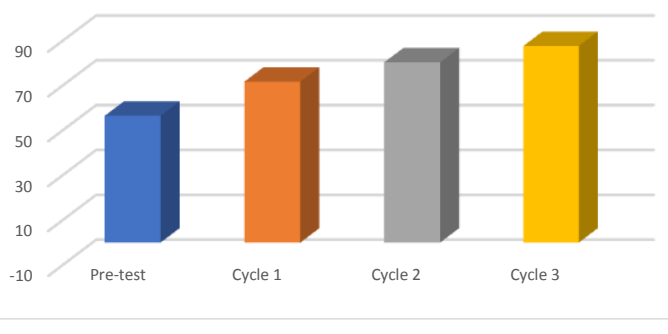

Fig. 3. The students' improvement in the speaking fluency.

Figure 3 shows that the students' speaking ability was significantly improved as the cycle continued. In accordance with the improvement, the communicative activities and practices applied to facilitate the learning activities were also created an active classroom interaction. In addition, the thing that could be reported based on the result of the application of guided discover-learning strategy here was the strategy of learning was also able to make the students practice their English lively and the generalization they made through the process of exploration would be long lasted in the sense that it was not easy to forget. Consequently, it was hoped that their English would become better as it was expected in the overall goal of the curriculum. Beside that the performance indicator which targeted the score of the students' English proficiency (TOEFL Like) $\geq 450 /$ TOEIC $\geq 500$ would be achieved and also the students' grade performance score (GPS) would increase too.

The students' responses toward the application of the modified-conventional method in the English subject matter showed positive indication. The evidence of this statement could be seen on the result of the application of the questionnaire $\mathrm{s}$ on each cycle. In the first cycle there was $21.75 \%$ of the students said that they were very happy and there was $69.57 \%$ of them said that they were happy, and $8.7 \%$ said that they were happy nor unhappy, when they were asked about the feeling and interest in learning English. Then there were $43.48 \%$ of the students said that communicative activities and practices with brain storming in group discussions and pair works were really helpful to improve their speaking ability, while $56.62 \%$ said that they were helpful. In terms of the use guided discovery-learning strategy to improve their interaction in the class, $30.43 \%$ of the students said that the technique was really helpful for them to interact each other, while $56.52 \%$ that it was helpful, and $14.04 \%$ said that in between. Moreover, $26.09 \%$ of the students said that they were very happy when they were given communicative activities and practices like in cycle 1 , while $52.1 \%$ said that they were happy, and the other $21.74 \%$ said that they were happy nor unhappy. And there were $17.39 \%$ of the students said that the technique applied in the learning strategy was really helpful to make them concentrated in the class, while $60.87 \%$ said that it was helpful, and the other $21.74 \%$ said that in between.

Meanwhile in the second cycle, the result of the questionnaire indicated that there were $73.91 \%$ of the students said that the language games were easy when they were done in groups, while the other $26.09 \%$ said they were easy and uneasy 
when they worked in groups. Then there were $65.22 \%$ of the students said that the practices with role-plays and pair works were easy, while the other $34.78 \%$ of them said that they were easy nor uneasy. Meanwhile, there were $30.34 \%$ of the students said that working in group and doing practices by using roleplays and pair works were also really helpful to improve their ability in speaking, while $60.87 \%$ said that they were helpful, and the other $8.70 \%$ said that in between. And then, $73.91 \%$ of the students said that the instructions given by the teachers were easy while $26.09 \%$ just felt in between. And on the other side there were $26.09 \%$ of the students said that they were really happy when they worked in group and did practices using role-plays and pair works while interact each other, while $60.87 \%$ of them said that they were happy, and the other $13.04 \%$ said that they were happy nor unhappy with them. Then in the third cycle, the result of questionnaire given by the researchers showed that most of the students said the problems that they often faced in speaking English where they did not feel confidence in speaking English because they were afraid of making mistakes in grammar and pronunciation besides the lack of vocabularies and expressions to say and also hard to understand others when they speak English fast. The whole description of administering the questionnaire, its result as it is shown in the figure below.

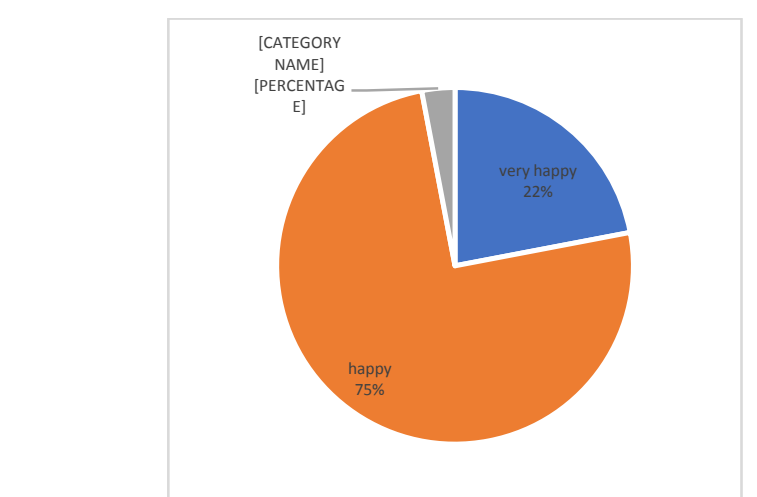

Fig. 4. Students' perception towards the implementation of modifiedconventional method

Most of the students said that the modified-conventional method used in the English class could minimize the problems faced by the students. It was due to the reason that communicative activities and practices were carried out excitingly, and also could release such feelings like boring, hesitate and afraid in learning. And one important thing said by the students was that the language items that had been learned were not easy to forget as they found them through learning process and not merely been told by the teachers. Then, they also listed some advantages of the guided discovery strategy such as the learning strategy could encourage them in speaking through the challenging technique applied in the classroom procedure like group discussions, language games, and problem solving. By the activities their interaction in the class could force them to be active during the learning process, they could enjoy the class, and did not feel boring in learning. The communicative activities and practices were also influencing the other language skills like listening, reading, and writing.
While the disadvantages of the learning method, they listed the points, like it was less efficient in times since it needs more time in finishing every unit due to the complexity of the class in the sense that they didn't have the same ability in understanding the materials. Some students need more time to catch them and slightly slow when they did oral presentation.

\section{CONCLUSION}

Based on the result of the findings and discussion stated earlier, it can be concluded that the application of the modifiedconventional method can improve the students' learning motivation and interest so that they can interact actively during the entire process of learning. The result of questionnaires distributed to the students after being given communicative activities and practices that facilitated their presentation in performing the speaking activities showed good findings in relation to the students' attention and response towards the application of the communicative activities and practices in the class. They felt that they could release the factors that cause unsecured learning in which often make them fail in using their English in the class. The integrated communicative activities and practices are really needed to be applied to the students so that they can practice their ability in English, especially in oral communication skill. Consequently, this high motivated learning situation can improve the oral communication of the fourth semester students of Travel and Tourism Study Program, State Polytechnic of Bali.

Considering on the conclusion formulated above, the essence of modified conventional method can be used as an alternative technique or activities in English class. The teacher should be active in facilitating the learning so that the exploration process prior to the stage of discovery can be created. The teacher's creativity in designing fun and lived communicative activities and practices will be able to stimulate their learning interest and motivation. Due to the complexity of classroom activities further research is needed in order to make the teaching learning process is more fun and exciting. In addition, the teacher can utilize information and communication technology (ICT) for more extra time of online learning to overcome the limit of time studying in the classroom. Through online learning the principal of any when, anywhere, and anyone can learn will be realized.

\section{ACKNOWLEDGMENTS}

The authors are very grateful to some parties who have given contributions and encouragements in completing this article. Particular thanks are owed to the following:

1. Kementerian Riset dan Technologi Pendidikan Tinggi or the Ministry of Technology and Research of Higher Education who funded the authors' research in the scheme of Penelitian Terapan Unggulan Perguruan Tinggi (PTUPT) or the Excellence of Higher College Applied-Research 2018 
2. State Polytechnic of Bali who funded the authors' research in the scheme of Penelitian Dipa unggulan 2018

3. Mr. I Ketut Suarta, the Head of Tourism Department and Mrs. A.A.A. N. Harmini, the head of Travel and Tourism Study Program, State Polytechnic of Bali who gave an access to the authors to conduct a research in the study program.

4. The fourth-semester students of Travel and Tourism Study Program in 2017/2018 academic year as the participants of the research.

5. Prof. Dr. Ni Putu Kerti Nitiasih, MA as an expert who standardized the research instrument.

6. Mrs. Ratih Oktarini and Mr. Rai Jaya Widanta, the authors' colleagues in the study program or the Institutional Language Centre who gave some language correction of the article.

\section{REFERENCES}

[1] Ali, S. D., \& Abdallaabdalganaem, M. (2014). Adopting Blended Learning Instruction to Promote Learner's Oral Competence. Research Journal of English Language and Literature, 2(4), 279-287.

[2] Ginaya, G., Rejeki, I.N.M. and Astuti, N.N.S., 2018. The effects of blended learning to students' speaking ability. International Journal of Linguistics, Literature and Culture (IJLLC), 4(3), pp.1-14.

[3] Marhaeni, A.A.I.N. (2017). "Pengembangan Rubrik untuk Optimalisasi Penilaian Kinerja Mahasiswa". A paper presented in the workshop of composing the assessment rubric in Tourism Department, Bali State Polytechnic June $16^{\text {th }} 2017$

[4] Greenhill, V. (2010). 21st Century Knowledge and Skills in Educator Preparation. Partnership for 21 st century skills.

[5] Framework for $21^{\text {st }}$ Century Learning. (n.d.). Retrived from http://www.p21.org/about-us/p21-framework.

[6] Shahidzade, Farangis, 2018. "Which Strategies Can Motivate EFL Learners More in Foreign Language Context? How?” (Research Gate, posted on 4 August 2018). https://www.researchgate.net/post accessed 5 August 2018.

[7] Somawati, N.P., Astuti, N.W., Kanca, I.N., Widanta, I.M.R.J. and Ardika, I.W.D., 2018, January. Task-based language teaching: how it is implemented effectively? In Journal of Physics: Conference Series (Vol. 953, No. 1, p. 012075). IOP Publishing.
[8] Richards, J.C. and Rodgers, T.S., 2014. Approaches and methods in language teaching. Cambridge university press.

[9] Thorsett, Peter., 2002. Discovery Learning Theory.(online) (http://www.limfaweb.weebly.com), retrieved on January $26^{\text {th }} 2018$.

[10] Richards, J.C. and Schmidt, R.W., 2013. Longman dictionary of language teaching and applied linguistics. Routledge.

[11] Holešinská, A., 2006. Teaching English as a foreign language to students with learning difficulties (Doctoral dissertation, Masarykova univerzita, Pedagogická fakulta).

[12] Balım, A.G., 2009. The Effects of Discovery Learning on Students Success and Inquiry Learning Skills. Eurasian Journal of Educational Research (EJER), (35)

[13] Nutting, C.M., 2013. Discovery-Based Learning in World Arts: Creativity and Collaboration in the Undergraduate Fine Arts Class. Teaching Innovation Projects, 3(1), p.12.

[14] Saumell, V., 2012. Guided Discovery for Language Instruction: A Framework for Implementation at All Levels. Buenos Aires: Person.

[15] Bilgin, I., Šenocalk, E. and Sözbilir, M., 2009. The Effects of ProblemBased Learning Instruction on University Students' Performance of Conceptual and Quantitative Problems in Gas Concepts. Eurasia Journal of Mathematics, Science \& Technology Education, 5(2).

[16] Rodríguez González, C.A. and Fernández Batanero, J.M., 2016. A review of Problem-Based Learning applied to Engineering. EduRe Journal: International Journal on Advancesin Education Research, 3(1), pp.14-31

[17] Caswell, C.A., 2017. Design and Facilitation of Problem-Based Learning in Graduate Teacher Education: An MA TESOL Case. Interdisciplinary Journal of Problem-Based Learning, 11(1), p.6.

[18] Mansor, A.N., Abdullah, N.O., Wahab, J.A., Rasul, M.S., Nor, M.Y.M., Nor, N.M. and Raof, R.A., 2015. Managing problem-based learning: Challenges and solutions for educational practice. Asian Social Science, 11(4), p.259.2015 ISSN 1911-2017 E-ISSN 1911-2025

[19] Burt, M. and Mathews-Aydinli, J., 2007. Promoting education and achievement of adults learning English. Center for Adult English Language Acquisition.

20] Eison, J., 2010. Using active learning instructional strategies to create excitement and enhance learning. Jurnal Pendidikantentang Strategi Pembelajaran Aktif (Active Learning) Books, 2(1), pp.1-10.

[21] Huang, K.S. and Wang, T.P., 2012. Utilizing problem-based learning $(\mathrm{PBL})$ in a university english interpretation class. The Journal of Human Resource and Adult Learning, 8(1), p.7.

[22] Mathew, R., 2015. Collaborative Learning-An Effective Method for Teaching Native Arabic

[23] Slavin, R.E., 2010. Co-operative learning: what makes group-work work. The nature of learning: Using research to inspire practice,

Kemmis, S., McTaggart, R. and Nixon, R., 2013. The action research planner: Doing critical participatory action research. Springer Science \& Business Media. 